\title{
The long way from bench to bedside
}

\author{
Olivier Gaide \\ From 5th International Conference on Ectodermal Dysplasia (ED2012) \\ Erlangen, Germany. 1-3 June 2012
}

Loss-of-function mutations in the ectodysplasin A gene, $E D A$, have been associated with $\mathrm{X}$-linked hypohidrotic ectodermal dysplasia (XL-HED) since 1996. In 2003, we made use of this information to engineer a recombinant soluble form of ectodysplasin A that has the potential to revert the disease in mice. Almost 10 years later, a cure is still not available for individuals affected by the disease. Is this normal? Part of the answer lies in the complexity of the process linking the proof of principle (in mice) and the authority-approved human treatment. It involves the production of a clinical grade pharmacological drug, a tricky process that requires clean-from-the-start-engineering and extensive stability/efficacy/toxicity controls at every step. And this is only the beginning. Defining treatment windows, regimens, doses and biomarkers of efficacy requires significant research efforts; often tedious and unlikely to be published in high-impact journals. Production and research must run in parallel to discussions with regulatory agencies, each process influencing the other. Finally, a wealth of clinical data must be put together, including precise natural history, identification and preparation of clinical centers, clinical trial protocols set up and filing. Taken together, these steps require two things: i) time and ii) dedicated professionals from many different fields: scientists, clinicians, pharmacologists, production experts, regulatory experts and, importantly, a strong industrial partner. It is a fascinating process, subject to delays and pitfalls, but essentially sound as it drives for the development of the safest and best drug possible.

Published: 25 May 2012

doi:10.1186/1746-160X-8-S1-I17

Cite this article as: Gaide: The long way from bench to bedside. Head \& Face Medicine 2012 8(Suppl 1):117.

Department of Dermatology, Geneva University Hospital, Switzerland

Submit your next manuscript to BioMed Central and take full advantage of:

- Convenient online submission

- Thorough peer review

- No space constraints or color figure charges

- Immediate publication on acceptance

- Inclusion in PubMed, CAS, Scopus and Google Scholar

- Research which is freely available for redistribution

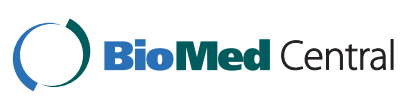

(C) 2012 Gaide; licensee BioMed Central Ltd. This is an Open Access article distributed under the terms of the Creative Commons Attribution License (http://creativecommons.org/licenses/by/2.0), which permits unrestricted use, distribution, and reproduction in any medium, provided the original work is properly cited. 